\title{
The Analysis of Learning Outcomes and Material Needs in Basic Accounting Workshop Learning
}

\author{
Ni Luh Gede Erni Sulindawati ${ }^{1, *}$ Made Ary Maitriana ${ }^{1}$ Nyoman Ayu Wulan Trisna \\ Dewi $^{1}$
}

\author{
${ }^{1}$ Department of Economic and Accounting, Universitas Pendidikan Ganesha, Singaraja, Indonesia \\ *Corresponding author. Email: erni.sulindawati@undiksha.ac.id
}

\begin{abstract}
With the Policy of the Minister about Merdeka Belajar-Kampus Merdeka, it is necessary to have an appropriate curriculum. Each curriculum contains learning outcomes and appropriate learning materials. Determination of learning outcomes is very necessary to determine the material being studied, strategies and appropriate media. Currently, the accounting workshop courses do not have achievements and learning materials that are in accordance with the demands of graduate users. Based on this, it is necessary to analyze the learning outcomes and appropriate materials. The purpose of this research was to analyze learning outcomes and appropriate materials for learning basic accounting workshops. The specific objectives to be achieved in this research are (1) the existence of learning outcomes in accordance with the implementation of independent campus and the needs of industry in the world of work and (2) the existence of appropriate materials to be learned in basic accounting workshop learning. This research used a qualitative research type, which was a research method to examine the condition of natural objects (without special treatment that is deliberately changed). The research approach chosen by the researcher was a descriptive approach. The results of the research according to information from graduate users and business people, there are four learning outcomes for attitudes, four learning outcomes for knowledge, and four learning outcomes for general skills that can be formulated and there are ten material coverage in accordance with the learning outcomes for basic accounting workshops.
\end{abstract}

Keywords: Achievements, Learning Materials, Basic Accounting Workshops.

\section{INTRODUCTION}

In accordance with "Permendikbud Number 3 of 2020 concerning National Standards for Higher Education, Article 18 states that the fulfillment of the learning period and load for undergraduate or applied undergraduate students can be carried out (1) following the entire learning process in study programs at universities according to the time and burden study and (2) following the learning process in the study program to fulfill part of the time and learning load and the rest following the learning process outside study program"[1], [2].

Merdeka Belajar-Kampus Merdeka, is a policy of the Minister of Education and Culture, which aims to encourage students are master various sciences that useful for entering the world of work. Merdeka Campus provides an opportunity for students to choose the courses they will take [1], [3].
With the Minister's Policy, it is necessary to have an appropriate curriculum. In the curriculum structure of the DIII accounting study program to implement the policy, there are field work practice programs, practicum that are in accordance with the expected competencies such as accounting practicum, taxation practicum, cost accounting practicum, public sector accounting practicum, and accounting computer applications as well as basic accounting and accounting workshops. financial accounting workshops.

For effective learning, it is necessary to analyze learning outcomes, materials, strategies and appropriate media to meet learning outcomes. Until now, in the learning of basic accounting workshops, problems are still encountered, where the appropriate learning outcomes, materials, strategies and learning have not been identified.

Therefore, it is important to research the needs for achievement and learning materials that are in accordance with the basic accounting workshop 
learning. The basic accounting workshop is a compulsory subject for accounting students. According to Suwardjono, accounting is seen as a tool for social institutions to provide measurement guidelines and methods to control the activities and behavior of dominant economic decision makers within the company or state, when viewed from the point of view of science and technology, it produces positive accounting theory and normative accounting theory. This classification is a logical consequence of defining accounting as a science and technology. Positive accounting theory contains statements about an event based on empirical observations, while normative accounting theory contains statements or reasoning based on value considerations [4], [5].

The definition of accounting has developed in accordance with changes in economic, social, cultural, legal, and government regulations. The definition of accounting is properly explained by three important characteristics of accounting, namely (1) Identification, measurement and combination of financial information about, (2) Economic entities to, (3) interested users [6].

Economic entities in the last 30 years have changed significantly both in terms of size and complexity. Likewise, interested users have increased substantially both in number and diversity. Accounting can also be understood from three points of view: (1) Service activities; (2) Field of study; (3) Process or activity. From activities, accounting services are services to provide quantitative information about economic business units, especially those of a financial nature that are useful in making economic decisions[7]. From the field of study accounting is defined as a set of knowledge which is the engineering of the provision of services in the form of quantitative financial information of an organizational unit and the method of delivering (reporting) that information to interested parties to be used as the basis for making economic decisions [8] [9].

From the accounting process or activity is defined as the process of identifying, measuring, recording, classifying, measuring, engineering and communicating financial information of economic entities in a certain way.

The final product of accounting is financial statements [10]. Complete financial statements consist of balance sheets, income statements, statements of changes in equity, cash flow statements, and notes to financial statements."[11], [12]. Financial statements must present fairly the financial position, financial performance, changes in equity, and cash flows of the company accompanied by disclosures in the notes to the financial statements in accordance with applicable standards [11], [12]. Types of business entities can be divided into three, namely trading companies, service companies, and manufacturing companies. The statement of financial position/balance sheet describes the financial position of an entity at a certain time, it can be a day, week, month, quarter, quarterly, semester and year. The balance sheet is a financial portrait of a company or entity at a certain time. The balance sheet describes the financial position and provides an overview of the company's ability to generate income or profits in the future [13].

The minimum balance sheet includes the following items: (a) cash and cash equivalents; (b) trade and other receivables; (c) inventory; (d) investment property; (e) fixed assets; (f) intangible assets; (g) trade payables and other payables; (h) tax assets and liabilities; (i) estimated liabilities; (j) equity [11].

The income statement includes all items of income and expense recognized in a period, the income statement at least includes the following items: (a) income; (b) financial burden; (c) share of profit or loss on investments using the equity method; (d) tax burden; (e) net profit or loss.’[11].

The statement of changes in equity presents, among others, the entity's profit or loss for a period, items of income and expenses recognized directly in equity for the period, the effects of changes in accounting policies and corrections of errors recognized in the period, and the amount invested by, and dividends and distributions. others to, owners of equity during the period [11].

Cash Flow Report, a cash flow report is a report that presents relevant information about cash revenues and expenditures of a business unit in one period to the next period [14].

The application of accounting theory in this study is focused on the application of accounting on the science and technology side. On the science side or field of science that contains knowledge tools in the preparation of financial statements. On the technology side, it contains the use of technology in the process of preparing financial reports which consists of activity steps. The steps of these activities include the first step of making journals, ledgers, trial balances, adjusting journals, work sheets, and preparing financial statements. In this basic accounting, the types of entities that are focused on are service and trading companies.

Learning materials will be contained in learning tools. According to Duniap.co.id, learning devices are a number of materials, tools, media, instructions and guidelines that will be used in the learning process. From this description, it can be stated that learning tools are a collection of media or facilities used by teachers and students in the learning process in the classroom [15]. Furthermore, according to Duniap.co.id, the types of learning devices consist of Syllabus. Education Calendar, Learning Implementation Plan, Student Activity Sheet, Books, and Assessment Instruments [15].

According to the Undiksha Development Guidebook (2016), learning tools include, syllabus, Lecture contract each subject is equipped with; (1) course syllabus, (2) semester learning plan, and (3) lecture contract. The syllabus is a set of plans regarding materials, activities, 
and learning management, as well as a form of assessment of learning outcomes for each course. The syllabus at least contains the identity of the course: name, code, credit-weights, prerequisite courses, course description, learning achievement. Outline of Learning Plan regarding the subject matter of learning, and Indicator is an elaboration of the course syllabus lectures developed by lecturers independently or together in expertise groups in a field of science and/or technology in the study program.

In accordance with the learning process standards of the National Higher Education Standards [16], Semester learning plan at least contains: name of study program, name and course code, semester, credits, name of supporting lecturer, graduate learning achievements that are charged to the course, final abilities planned at each learning stage to meet learning outcomes graduates, study materials related to the abilities to be achieved, learning methods, time provided to achieve abilities at each stage of learning [17], [18], student learning experience embodied in the description of tasks that must be done by students for one semester, criteria, indicators, and assessment weights; and a list of references used [18]. Lecture contracts are key points (summaries) whose scientific content is transferred from the Semester Lesson Plan that has been prepared by individual lecturers and/or scientific groups, but technical and normative matters are an agreement between lecturers and students. This lecture contract is given to students and then used as a reference in attending lectures. The points contained in the lecture contract, at least as follows, Course Identity, Course Description, Learning Outcomes, Learning Methods, Reading Materials, Assignments or Obligations, Assessment Criteria, and Lecture schedule [19].

Learning tools in the right basic accounting workshops need to be researched and analyzed through studies of expected learning outcomes, input and suggestions from the relevant industry, and competent teaching staff who master their fields. Learning tools are needed to facilitate and as a reference in making learning effective. The learning kit contains a syllabus, lecture contracts, semester lesson plans, and student assignment plans. The syllabus contains appropriate learning strategies, approaches and techniques, required learning materials, learning media, facilities and infrastructure needed in the workshop as well as the necessary evaluation tools.

Based on this, in this study, the expected learning outcomes will be analyzed, as well as the materials needed to fulfill learning outcomes in basic accounting workshop learning.

The purpose of this study is to analyze learning outcomes and learning needs and learning materials in learning basic accounting workshops. The specific objectives to be achieved in this study are: (1) the existence of learning outcomes that are in accordance with the implementation of an independent campus and the needs of industry in the world of work (2) the existence of appropriate materials to meet the learning competencies of basic accounting workshops.

With the implementation of this research, it will also make a positive contribution to the institution, especially in the context of playing a role in the development of learning outcomes and appropriate materials to complement learning tools in basic accounting workshop learning. This learning tool produced will be able to become a reference for accounting teachers and students in terms of understanding basic accounting.

\section{METHOD}

This study uses a qualitative research type, which is a research method to examine the condition of natural objects (without special treatment that is intentionally changed) [20]. The research approach chosen by the researcher is a descriptive approach. Descriptive approach is used based on the consideration that the problems to be studied are currently taking place which aims to analyze events that occur in the field and then expressed in the form of narratives and descriptions. Because it uses a descriptive approach, the presence of researchers at the research site or in the field is very necessary. The researcher is a key instrument that tries to record all events and events that occur in the field. In addition, researchers also try to adapt the situation and conditions that exist in the field without giving a special need that is made intentionally, and trying to create good relationships with informants related to research. Sources of data in this study obtained from informants considered the most important to know in detail and clearly about the focus of the research, which is related to the achievements and learning materials of basic accounting workshops. The informants are leaders and accounting departments in various industries in the province of Bali. This researcher used three techniques to obtain data in the field, namely: interview, observation and documentation techniques. The data wetness test used triangulation, namely technical triangulation and source triangulation. Data analysis in this study refers to the qualitative analysis stated by Miles and Huberman. The stages used in conducting data analysis are: data reduction data display, conclusion and data verification [21].

\section{RESULTS \& DISCUSSION}

The results of the study of basic accounting workshop learning competencies obtained through interviews and distributing questionnaires to company leaders and accounting staff in various industries can be described as follows.

Ocean Bali Medewi in Jembrana Regency Activities that have been carried out are cleaning and selling products from the results of recycling, the task of the 
accounting department updating daily and monthly cash flow data, recapitulation of salaries. The expectation of the accounting staff is to master Microsoft excel, word and its formulas.

Following are the results of an interview with the Alas Harum Bali Hotel in Gianyar Regency, it is known that the activities that have been carried out are coffee and restaurants. The task of the accounting department is to record transactions, report the use of company funds. The company leadership expects its accounting staff to be able to record direct transactions and update the transaction methods applied in every tourism business.

The head of Nau Villa Ubud in Gianyar Regency said that the activities he had carried out were in the form of humiliation activities. The leadership of Nau Villa Ubud expects the accounting department to make payments, check payment receipts, deposit cash receipts to the bank, receive goods, make journals and supervise raw materials. The hope of the leadership of nau Villa Ubud is to have skills in the field of accounting and in the community.

The head of Uma Ceking Resto in Gianyar Regency informed that the activities he had carried out were restaurant activities and swing and photo booth activities. The duties of the accounting department at the company are checking the entry and exit of goods, checking company finances, recording all sales every day, making payments, checking payment receipts, depositing cash receipts to the bank, receiving goods, journaling and recording and supervising existing raw materials. The hope of the leadership of Uma Ceking Resto for its accounting department is to have skills in the field of accounting.

According to the principal of CV Bhina Karya in Jembrana Regency, the activities that have been carried out by contractors and suppliers. The job of the accounting department is to record all income and expenses. The leader's expectation is to have skills in the field of accounting, discipline, thorough and punctual.

From the results of the interviews and the distribution of the questionnaire above, it can be concluded that the material in accordance with the tasks given by the accounting department in various companies includes making daily journals, diaries relating to each transaction, both related to company income and expenditure transactions, recording income and expenditure of goods, prepare financial reports such as income statements, cash flow statements. Skilled in using Microsoft Word and Excel programs, as well as having an honest attitude and ability to cooperate, carefully and thoroughly.

\subsection{Curriculum Analysis}

In accordance with the Undiksha curriculum guidebook, compulsory basic accounting workshop courses are also prepared, learning outcomes are contained in the syllabus, lecture contracts, Semester Learning Plans, and Student Assignments.

From the analysis of material needs from various leadership and accounting staff, learning outcomes can be arranged which can be seen in the following table. From Table 1. Learning Outcomes of Basic Accounting Workshops, it can be seen that in the basic accounting workshop learning there are four learning outcomes for attitude, four learning outcomes for knowledge, and four learning outcomes for general skills. From the learning achievements that can be identified, an analysis is then carried out involving subject lecturers who have expertise in the field of accounting, the coverage of learning materials is summarized in Table 2.

The ability of the accounting department that is expected by the leadership in various companies, namely in making daily journals, keeping a diary related to each transaction, both related to the company's income and expenditure transactions, is contained in the first, second and third material coverage. The scope of the material is an accounting system and recording transactions into the basic accounting equation, accounts, and service company accounting processes. The ability to record the entry and exit of goods is contained in material scope of Inventory Accounts and Special Journals in trading companies. The ability to prepare financial statements such as income statements, cash flow statements is contained in the sixth, seventh, eighth and ninth material coverage. The scope of the material is the environment and accounting framework, income statement and retained earnings, balance sheet and cash flow statements. Skilled in using Microsoft Word and Excel programs contained in the tenth material coverage, namely Financial Reports with Word and Microsoft Excel programs.

\section{CONCLUSION}

According to information from graduate users and business people, there are four learning outcomes at the Basic Accounting Workshop, four learning outcomes for knowledge, and four general skills learning outcomes that can be formulated. There are ten material coverages to meet learning outcomes.

\section{ACKNOWLEDGMENTS}

Thanks are conveyed to the leadership of the Research Institute, Postgraduate Leaders, and the Faculty of Economics, Ganesha University of Education for facilitating the author to complete this paper. 
Table 1. Learning Objectives

\begin{tabular}{|c|c|c|c|}
\hline No & Attitude learning achievement & Knowledge learning achievement & General Skills learning achievement \\
\hline 1 & $\begin{array}{l}\text { Upholding human values in } \\
\text { carrying out tasks based on } \\
\text { religion, morals and ethics }\end{array}$ & $\begin{array}{l}\text { Mastering theoretical concepts in the } \\
\text { accounting field and having the ability } \\
\text { to complete a wide-ranging work in the } \\
\text { field which is his field of application by } \\
\text { choosing the appropriate method from } \\
\text { a variety of choices that are already or } \\
\text { not standardized by analyzing related } \\
\text { data }\end{array}$ & $\begin{array}{l}\text { Have the ability to carry out all } \\
\text { stages of the accounting cycle in } \\
\text { various types of businesses, both } \\
\text { service and trading companies }\end{array}$ \\
\hline 2 & $\begin{array}{l}\text { Demonstrate a responsible } \\
\text { attitude towards work in their } \\
\text { area of expertise } \\
\text { independently. }\end{array}$ & $\begin{array}{l}\text { Mastering the theoretical concepts of } \\
\text { accounting in general and other } \\
\text { concepts relevant to solving problems } \\
\text { and / or work in the field of accounting } \\
\text { in service companies. }\end{array}$ & $\begin{array}{l}\text { Have the ability to prepare } \\
\text { various financial statements of } \\
\text { the entity both in the balance } \\
\text { sheet, profit and loss, cash flow } \\
\text { and equity statements. }\end{array}$ \\
\hline 3 & $\begin{array}{l}\text { Have an honest personality } \\
\text { and empathetic and } \\
\text { humanistic social interactions. }\end{array}$ & $\begin{array}{l}\text { Mastering the basic scientific concepts } \\
\text { and skills in the field of accounting. }\end{array}$ & $\begin{array}{l}\text { Able to apply accounting in } \\
\text { various business services and } \\
\text { trading businesses. }\end{array}$ \\
\hline 4 & $\begin{array}{l}\text { Cooperate and have social } \\
\text { sensitivity and concern for } \\
\text { society and the environment. }\end{array}$ & $\begin{array}{l}\text { Mastering the basic concepts of skills in } \\
\text { operating the excel program in } \\
\text { compiling financial reports. }\end{array}$ & $\begin{array}{l}\text { Have skills in applying Microsoft } \\
\text { Word and Excel programs in } \\
\text { preparing financial reports }\end{array}$ \\
\hline
\end{tabular}

Table 2. Learning Outcomes of Basic Accounting Workshop

\begin{tabular}{|c|c|c|c|}
\hline No & $\begin{array}{l}\text { Learning Outcomes Course } \\
\text { Achievement }\end{array}$ & Indicator & Scope of Material \\
\hline 1 & $\begin{array}{l}\text { Understand the accounting } \\
\text { system and its development }\end{array}$ & $\begin{array}{l}\text { 1.1. Able to show the articulation of a simple set of } \\
\text { financial statements } \\
\text { 1.2. Be able to name and explain important } \\
\text { concepts in accounting and show the } \\
\text { implications they follow } \\
\text { 1.3. Able to analyze financial transactions and show } \\
\text { their effect on the company's financial position } \\
\text { on the basis of the concept of a business unit } \\
\text { 1.4. Able to record financial transactions into } \\
\text { embryonic accounting system } \\
\text { 1.5. Able to explain the meaning of the accounting } \\
\text { equation and its relation to the articulation of } \\
\text { financial statements }\end{array}$ & $\begin{array}{l}\text { Accounting system } \\
\text { and recording } \\
\text { transactions into the } \\
\text { basic accounting } \\
\text { equation }\end{array}$ \\
\hline
\end{tabular}




\begin{tabular}{|c|c|c|c|}
\hline No & $\begin{array}{l}\text { Learning Outcomes Course } \\
\qquad \text { Achievement }\end{array}$ & Indicator & Scope of Material \\
\hline & & $\begin{array}{l}\text { 1.6. Able to record transactions to prepare financial } \\
\text { statements with a simple accounting system }\end{array}$ & \\
\hline 2 & $\begin{array}{l}\text { Understand transaction } \\
\text { analysis } \\
\text { accounts/accounts/estimates }\end{array}$ & $\begin{array}{l}\text { 2.1. Able to explain the meaning of accounts, } \\
\text { account classification, and forms of accounts } \\
\text { 2.2. Able to explain the meaning of ledger } \\
\text { 2.3. Able to analyze transactions in debit credit } \\
\text { rules and normal balances } \\
\text { 2.4. Able to explain the essence of double } \\
\text { bookkeeping } \\
\text { 2.5. Able to analyze and summarize transactions } \\
\text { using accounts }\end{array}$ & Account \\
\hline 3 & 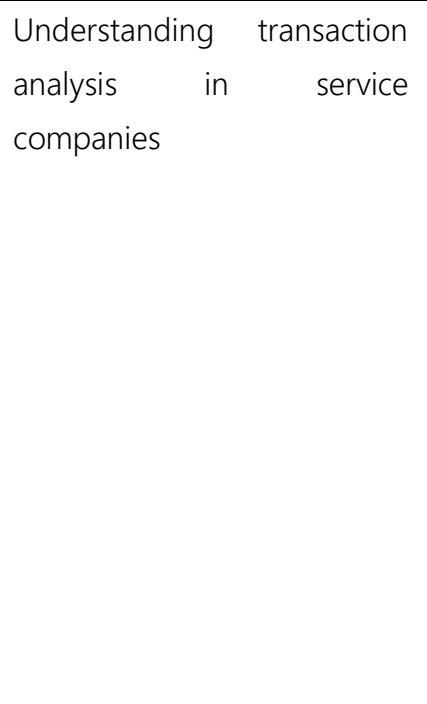 & $\begin{array}{l}\text { 3.1. Able to explain the meaning of the accounting } \\
\text { cycle } \\
\text { 3.2. Able to analyze and record transactions in } \\
\text { general journals } \\
\text { 3.3. Able to post in the ledger } \\
\text { 3.4. Able to explain the concept of matching and } \\
\text { make adjusting journal entries for service } \\
\text { companies } \\
\text { 3.5. Able to prepare balance sheet } \\
\text { 3.6. Able to compile financial reports of service } \\
\text { companies } \\
\text { 3.7. Able to make closing journal entries and closing } \\
\text { trial balance }\end{array}$ & $\begin{array}{l}\text { Service company } \\
\text { accounting process }\end{array}$ \\
\hline 4 & $\begin{array}{l}\text { Have the skills, knowledge, } \\
\text { and work attitudes needed } \\
\text { to manage inventory cards } \\
\text { in accordance with the } \\
\text { procedures established by } \\
\text { the company }\end{array}$ & $\begin{array}{l}\text { 4.1. Able to prepare inventory card management } \\
\text { 4.2. Able to identify inventory mutation data } \\
\text { 4.3. Able to record inventory mutations to inventory } \\
\text { cards } \\
\text { 4.4. Able to make inventory reports } \\
\text { 4.5. Able to record thr difference in inventory } \\
\text { 4.6. Able to classify inventory } \\
\text { 4.7. Able to explain the cost of inventory } \\
\text { 4.8. Able to explain cost flow assumptions } \\
\text { 4.9. Able to explain and be able to apply the } \\
\text { method of recording inventory } \\
\text { 4.10. Able to make inventory valuation based on cost } \\
\text { method, cost method or lower market price, } \\
\text { estimation methods, gross profit method and } \\
\text { retail price method } \\
\text { 4.11. Able to present inventory report Inventory } \\
\text { Account }\end{array}$ & Inventory Account \\
\hline
\end{tabular}




\begin{tabular}{|c|c|c|c|}
\hline No & $\begin{array}{l}\text { Learning Outcomes Course } \\
\text { Achievement }\end{array}$ & Indicator & Scope of Material \\
\hline 5 & $\begin{array}{l}\text { Understand transaction } \\
\text { analysis using special } \\
\text { journals }\end{array}$ & $\begin{array}{l}\text { 5.1. Able to analyze transactions in the sales book } \\
\text { 5.2. Able to analyze transactions in the cash receipts } \\
\text { book } \\
\text { 5.3. Able to analyze transactions in the purchase } \\
\text { book } \\
\text { 5.4. Able to analyze transactions in the cash } \\
\text { disbursement book } \\
\text { 5.5. Able to perform posting process in general } \\
\text { ledger and subsidiary ledger }\end{array}$ & $\begin{array}{l}\text { Journal in trading } \\
\text { company }\end{array}$ \\
\hline 6 & $\begin{array}{l}\text { Understand financial } \\
\text { statements, accounting, and } \\
\text { the framework that underlies } \\
\text { financial statements }\end{array}$ & $\begin{array}{l}\text { 6.1. Able to explain the meaning and types of } \\
\text { financial statements } \\
\text { 6.2. Able to explain the scope of accounting } \\
\text { 6.3. Able to explain the framework that underlies } \\
\text { the environmental financial statements and } \\
\text { accounting framework }\end{array}$ & $\begin{array}{l}\text { Environmental } \\
\text { financial statements } \\
\text { and accounting } \\
\text { framework }\end{array}$ \\
\hline 7 & $\begin{array}{l}\text { Understand the income } \\
\text { statement and the } \\
\text { limitations of the loss } \\
\text { statement and income } \\
\text { statement on hold }\end{array}$ & $\begin{array}{l}\text { 7.1. Able to explain the income statement } \\
\text { 7.2. Able to explain the limitations of the Profit and } \\
\text { loss report } \\
\text { 7.3. Able to explain the Retained Earnings report }\end{array}$ & $\begin{array}{l}\text { Profit and Loss } \\
\text { Statements on hold }\end{array}$ \\
\hline 8 & $\begin{array}{l}\text { Understand the usefulness } \\
\text { of the Balance Sheet, the } \\
\text { limitations of the Balance } \\
\text { Sheet and the components } \\
\text { of the Balance Sheet }\end{array}$ & $\begin{array}{l}\text { 8.1. Able to explain the use of balance sheet } \\
\text { 8.2. Able to explain the limitations of the balance } \\
\text { sheet } \\
\text { 8.3. Able to explain the components of the balance } \\
\text { sheet }\end{array}$ & Balance Sheet \\
\hline 9 & $\begin{array}{l}\text { Make a cash flow statement } \\
\text { and explain the usefulness of } \\
\text { the cash flow statement }\end{array}$ & $\begin{array}{l}\text { 9.1. Able to make cash flow reports } \\
\text { 9.2. Able to explain the usefulness of the Cash Flow } \\
\text { Statement }\end{array}$ & Cash Flow Statement \\
\hline 10 & $\begin{array}{l}\text { Prepare financial reports } \\
\text { using Word and Microsoft } \\
\text { Excel }\end{array}$ & $\begin{array}{l}\text { 10.1. Able to prepare financial reports using } \\
\text { Microsoft Excel program } \\
\text { 10.2. Able to present financial reports with word } \\
\text { program }\end{array}$ & $\begin{array}{l}\text { Financial reports with } \\
\text { Word and Microsoft } \\
\text { Excel programs }\end{array}$ \\
\hline
\end{tabular}

\section{REFERENCES}

[1] M. Tohir, "Buku Panduan Merdeka Belajar Kampus Merdeka," 2020, doi: 10.31219/osf.io/ujmte.

[2] Kompasiana, "Mengenal Merdeka Belajar Kampus "Merdeka," https://www.kompasiana.com/fideliawf8597/5fb4lf b48ede484869198f42/mengenal-merdeka-belajar- kampus-merdeka, 2020.

[3] Dikti, "Buku Panduan," http://dikti.kemdikbud.go.id/wpcontent/uploads/2020/04/Buku-Panduan-MerdekaBelajar-Kampus-Merdeka-2020, 2020.

[4] Suwardjono, Teori Akuntansi, vol. 53, no. 9. 2016.

[5] R. B. Purba, . N., and S. Tambunan, "Perspectives of Accounting Theory," J. Econ. Bus. Account. 
Ventur., vol. 21, no. 1, pp. 137-141, 2018, doi: 10.14414/jebav.v21i1.1167.

[6] J. J. Keiso, Donald E dan Weygad, Intermediate Accounting, Jakarta: Penerbit Erlangga. 2011.

[7] Lestari Rahayu, MODUL MATA KULIAH DASAR AKUNTANSI PROGRAM STUDI AGRIBISNIS "Perusahaan Jasa." 2016.

[8] E. A. Osadchy, E. M. Akhmetshin, E. F. Amirova, T. N. Bochkareva, Y. Y. Gazizyanova, and A. V. Yumashev, "Financial statements of a company as an information base for decision-making in a transforming economy," Eur. Res. Stud. J., vol. 21, no. 2, pp. 339-350, 2018, doi: 10.35808/ersj/1006.

[9] Faulifa, "Pengertian Akuntansi beserta Sejarah dan Tujuan Akuntansi yang Perlu Anda Ketahui," https://familinia.com/pengertian-akuntansi/, 2017.

[10] DIA, "Memahami Logika Laporan Keuangan (Neraca dan Laba Rugi)," https://akuntansidia.wordpress.com/2015/12/04/m emahami-logika-laporan-keuangan-neraca-danlaba-rugi/, 2015.

[11] Ikatan Akuntan Indonesia, Standar Akuntansi Keuangan ETAP. 2009.

[12] Witdya Pangestika, "Laporan keuangan," https://www.jurnal.id/id, 2020.

[13] J. Badruzaman and D. Kusmayadi, Akuntansi Hotel, no. May 2014. 2014.

[14] N. Sulindawati, "An Analysis of Instructional Material Need For Improving Students ' Ability in Writing Cash Flow Reports," vol. 134, no. Icirad, pp. 146-152, 2017.

[15] duniapcoid, "Jenis Perangkat Pembelajaran," https://duniapendidikan.co.id/perangkat-

pembelajaran/, 2021.

[16] U. Pgri, A. D. I. Buana, and U. Surabaya, "PROGRAM STUDI ( $\mathrm{S}-1$ ) KURIKULUM UNIPA SURABAYA 2015," https://pwk.unipasby.ac.id/wpcontent/uploads/2019/03/Template-KurikulumPWK-2015-2020-1.pdf, 2019.

[17] Silabus Web, "Pengertian Rencana Pembelajaran Semester," https://www.silabus.web.id/pengertian- rencana-pembelajaran-semester-rps/, 2020.

[18] T. P. SPMI, "Standar Nasional Pendidikan Tinggi," https://usd.ac.id/lembaga/lpmai/wpcontent/uploads/2019/04/2.-Standar-Nasional-

Pendidikan-Tinggi-SN-Dikti.pdf, 2020. http://www.kopertis12.or.id/wpcontent/uploads/2014/06/permen_tahun2014_nom or049.pdf.

[19] Tim Pengembang Undiksha, "Kurikulum,” 2016.

[20] Sugiyono, Metode Penelitian Kuantitatif Kualitatif dan $R \& D .2014$.

[21] A. . Miles, M. B. \& Hubberman, Analisis Data Kualitatif: Buku Sumber Tentang Metode-metode Baru. 1992. 